Кристина Димовска

\title{
ЗА ДИСТИНКЦИЈАТА МЕЃУ ТЕРМИНИТЕ „ЈУНАК“ И „ХЕРОЈ“ И НЕЈЗИНАТА ВАЖНОСТ ВО ТОЛКУВАЫЕТО НА ЕПСКИТЕ ПЕСНИ ${ }^{1}$
}

Апстракт: Трудот претставува резултат на потребата да се направи и да се прави дистинкцијата меѓу термините ,јунак“ и „херој“ во епските песни, да се објасни нејзината важност и да се дадат насоки за понатамошни толкувања и на други книжевни жанрови/родови, а не само на/во епиката. Потребата за ваква дистинкција се должи на суштинската, семантичка, а не етимолошка разлика меѓу ,јунакот“ и „херојот“ во една епска песна како вредносни критериуми што можат да резултираат со погрешно валоризирање на еден јунак како херој или воопшто на едно дело како

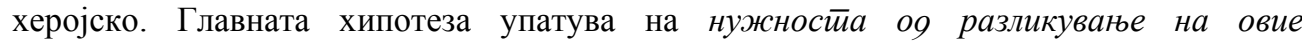

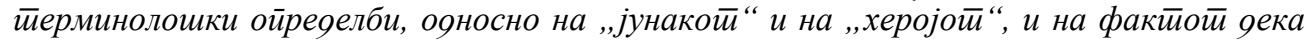

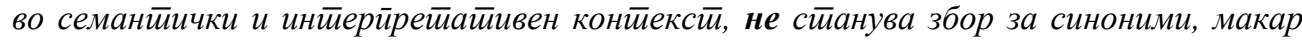

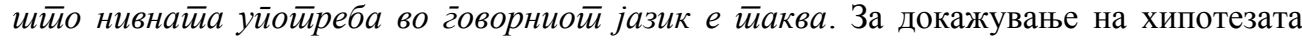
треба да послужат општиот аналитички и синтетички метод, како и посебните методи на компаративно и на интертекстуално проучување. Обидите за докажување на хипотезата е низ примери од јужнословенските, односно македонските епски песни за Марко Крале и за Турунџула Каравлашки, врз основа на нивната заемна сличност како ликови и како јунаци, а заклучокот на трудот упатува на нијансите како клучни во семантичкото разликување на овие два термини.

Клучни зборови: епска песна, лик, јунак, херој, протагонист, антагонист, антијунак/антихерој/ахерој.

\section{1. Теориски дел: терминолошки дистинкции}

Трудов ја проблематизира потребата од дистинкција меѓу терминолошките определби ,јунак“ и „херој“ при толкувањето на јужнословенските, односно на македонските епски песни, кои вообичаено имаат централна фигура со одреден склоп на атрибути што го определуваат како ваков или како онаков тип на дејствувач во епското дејство. За да може да се дојде до дистинкцијата што е погоре предложена, нужно е најпрвин да се објаснат некои термини дадени во клучните зборови.

\footnotetext{
${ }^{1}$ Трудов претставува резултат на дискусијата, којашто се загатна на научниот собир „70 години Институт за фолклор и 50 години фолклористичка дејност на Иван Котев“, којшто се одржа на 27 и на 28 август 2021 г. во Струмица.

И покрај тоа што во насловот се забележува дека дистинкцијата меѓу двата опфатени термини е предложена да се прави во епските песни, сепак тоа не значи дека интерпретативните амбиции треба да завршат само таму туку, напротив, од епиката можат да преминат и да се применат и во други книжевни, но и некнижевни родови и видови каде што се проблематизира херојството како централна тема.
} 
Со терминот лик, којшто е генеричка категорија, се именува главниот дејствувач, но и споредните дејствувачи во епското дејство, коишто вршат одредена улога и функција во сижето и не се попусто или напразно дадени. Главниот лик вообичаено е централно поставен и е еден, наспрема многуте споредни, пропратни ликови кои се секундарни и кои можат да бидат негови придружници или непријатели, или пак можат да бидат и на маргините на сижето, според видот на своето дејствување. Ликовите можат да имаат позитивни или негативни атрибути или карактеристики, да бидат благонаклонети или спротивставени едни со други, или спрема главниот лик, да вршат функција на помагачи или одмагачи на остварувањето на одредени мисии или задачи на главниот лик, или пак на другите, споредни ликови.

Примери за ликови во епските песни за Марко Крале се сите главни и споредни ликови што се споменуваат во сижето, какви што се: Марко Крале, но и Ангелина/Марковица, Секула Детенце, Шарко/Шарец, односно ликот на Турунџула Каравлашки, но и ликот на неговата мајка, на Мара Меанџиката, на Сонцето, на коњчето, на Димо Чекундара и др. во епските песни за Турунџула Каравлашки.

Под терминот протагонист се подразбира главниот, стожерен лик во епското дејство, којшто, поради својата централна позиционираност во настаните опишани во епската песна, добива „најдетален“ третман односно, посветено му е најголемо внимание. Тој е повластен и привилегиран во споредба со останатите ликови. Термините „протагонист“ и „главен лик“ се синоними, но еден спореден лик не може да биде протагонист. Протагонистот се издвојува во епското дејство не поради своите позитивни или негативни карактеристики или атрибути туку попрво поради својата централна позиционираност и поради тоа што околу него се вртат сите настани во епската песна. Тој е присутен во сите стадиуми на развојот на сижето. Терминот „протагонист“ би бил најсоодветниот ако се сака да се избегне синонимијата меѓу термините ,јунак“ и „херој“ и може да се однесува на секој централен лик во еден книжевен или некнижевен текст, под услов, развојот на текстот да не може да се одвива без неговото присуство. Пример за протагонист може да е и самиот Марко Крале или Турунџула Каравлашки, но може да е и Волкашин („Марко и трите наречници“ кај Цепенков), ${ }^{2}$ Шарец („Марко и Гино Арнаутче“ кај Миладиновци) или мајката во песните за Турунџула, зашто ова се ликови кои не секогаш поседуваат само и единствено позитивни атрибути. Тие често пати се суптилен одраз на двојството (односно на дивергентноста) на човековата природа: тој (протагонистот) е истовремено и чувар на народот (поборник за колективното добро), но и, според современите, „строги“ критериуми за „добро однесување“ (се мисли на

\footnotetext{
2 Во литературата, на крајот од трудов, се наведени изворите од каде што се цитираат песните. Сите останати песни за Марко Крале се цитираат според: Блаже Петровски. 1969. Прег̃леg на макеgонскийе нарояни иеесни за Крали Марко. Скопје: Институт за фолклор „Марко Цепенков“, освен ако не е наведено поинаку.
} 
социјално прифатливо) тој е и алхохоличар (незаситен, лаком и прекумерен во своите апетити).

Како противтежа на протагонистот е антагонистот, којшто го претставува „негативецот“ во епското сиже и негова улога е ефективно да ги спречи напорите на протагонистот за постигнување на замисленото. Антагонистот, како и протагонистот, не поседува негативни и само негативни атрибути или, поправо, опсегот на неговите негативни атрибути се должи на тоа шйо читателот или толкувачот на епската песна определува како негативно. Дали Дука од песната „Крале Марко и канли Дука“ треба да се окарактеризира како антагонист со исклучително негативни атрибути само затоа што го измамува Марко да го погледне сонцето? Не е ли просто тоа итрина, досетливост или снаодливост? Не се ли овие човекови особини вредни за подражавање ${ }^{3}$ Веројатно, поеклатантен пример за антагонист во вистинска смисла на зборот, е Јурум Кесеџија, кој во песната „Разболал ми се Крали Марко“ ги убива деветте деца на умрениот Марко.

Меѓутоа, дали поседувањето на „позитивни“ или на „негативни“ атрибути е воопшто плаузибилно во еден книжевен текст, - ако се сложиме дека епската песна може да се интерпретира исто како што би се интерпретирал еден книжевен текст - кој недоволно длабоко, прецизно и темелно ги претставува протагонистите и антагонистите, како што тоа би било случај со еден психолошки роман? Веројатно не, затоа што во епската песна не постои намера протагонистите и антагонистите да се претстават во нивната целосност или слоевитост каков што, веројатно, би бил случајот во еден роман, па затоа, поседувањето или непоседувањето на позитивни или на негативни атрибути, е во полза на контрастот и на разликата на протагонистот од антагонистот, иако ваквата „црно-бела“ разлика е само површна.

Кога веќе се дефинирани погореразгледаните терминолошки одредници, вреди да се обрне внимание на термините ,јунак“ и „херој“ во епските песни. Етимологијата тука нема да биде од помош иако и таа (во зависност од консултираните извори), ја илустрира суптилната разлика околу тоа како ги разбираме. „Понекогаш етимологијата ја изневерува смислата за јазикот и сфаќањето на одредени определби. Веќе не е доволно да се познава етимологијата за да можат контекстуално да се дефинираат одредени термини. А дури и кога добро се владее и се познава етимологијата, сепак тоа знаење нема да биде секогаш од полза при редефинирањето на оние термини што 'ни се веќе добро познати““ (Димовска 2019: 95). Уште руските формалисти беа свесни дека понекогаш одредени термини треба да се дезавтоматизираат, да се преосмислат со ново значење, од причина што или се загубила врската со нивното првично, оригинално значење, или тие почнале погрешно да се употребуваат (како во случајот со зборовите „морално“ и „задолжително“)

\footnotetext{
3 Дука успешно манипулира со Марко Крале и тоа го тера толкувачот да размисли дали можеби манипулацијата како особина не е пожелна, ако со неа се остварува (возвишена) цел.
} 
или да се злоупотребуваат (како што е со терминот „херојски“ и неговите изведенки). Добар пример за наивното служење со јазикот е синонимната употреба на термините ,јунак“ и „херој“ и погрешниот контекст во кој се употребуваат тие ја начнува потребата за нивно ново, или барем поразлично, дефинирање.

Во речниците достапни онлајн, описната дефиниција на терминот ,јунак“ се поистоветува со терминот „херој“ (јунакот е „оној кој се одликува со храброст и смелост; херој“4). Дефиницијата не е погрешна од проста причина што при дефинирањето на кој било термин во еден речник, лексикон или толковник, по правило се избегнува употребата на истиот термин во дефиницијата затоа што овој се смета за непознат, па затоа се користат синоними што асоцираат на него и помагаат во неговото уточнување. Во случајов, тоа е наширокоприфатениот термин „херој“. Исто така, предвид треба да се земе дека речниците, лексиконите и толковниците се напишани со цел човек да добие општа, површинска претстава за значењето на даден термин, да се информира за неговото значење, а не длабоко, филозофски и шпекулативно да навлегува во потенцијалните дополнителни или можни значења на зборот или терминот. Просто кажано, терминот „херој“ во цитираниот речник служи само како терминолошка супституција/синоним за најлесно, најбрзо и најбезболно да се објасни терминот ,јунак“. Во речниците нема простор за надолги и нашироки објаснувања и појаснувања. Ова го покренува прашањето: ако термините „,унак“ и „херој“ навистина се синоними, тогаш зошто во секојдневниот говор почесто се вели дека некој е херој затоа што постигнал некое храбро дело, а не се вели дека е јунак? Дали „обичниот“ човек, кој често пати е некнижевно образуван или барем не доволно, смета дека зборот ,јунак“ е архаичен, па затоа, за да му даде „бомбастичност“ на својот еуфистички извештај за нечие несебично, храбро дело, го употребува зборот „херој“ или неговата изведенка „херојски“" ?5

4 „Јунак, значење и дефиниција“. jezikoslovac.com. Во литературата на крајот од трудов се наведени сите електронски извори.

5 Вакви примери се среќаваат во македонските електронски медиуми: „ХЕРОЈСКИ. Македонија славеше против Шкотска“; претседателот на РСМ смета дека македонските фудбалери одиграле херојски на светското фудбалско првенство (пренебрегнувајќ́ го фактот дека тие загубија на светското првенство); „херојски: се врати по тешката скршеница на черепот“, но и „17-годишниот херој спасувач од Истанбул“ (курзиви К. Д.). По случајност сите наведени примери се од областа на спортот, но, дури и ова сведочи во колкава мера е искривоколчена употребата на квалификативите „херој“/,херојски“ и дека термините се користат и за губитници, што е спротивно на нивната суштина. Дополнително на ова, употребата на терминот е сведена на известувања и написи за сосема тривијални, ефемерни и минливи настани празни од грандиозно значење или општочовечка корист. По непишано правило, терминот би требало да се користи за да се овековечат перенијални, ретки и несекојдневни настани кои се добри и полезни за човештвото, кои упатуваат и сведочат за неговиот напредок и развој, а не за да се слават и воспеваат често пати дегенеративните и хуманистички контрапродуктивни анимални инстинкти. 
Иако етимологијата не е клучна за исцртувањето на дистинкцијата меѓу „јунакот“ и „херојот“, сепак, може да помогне во согледувањето на нијансите меѓу нив што пак, следствено, ќе укаже на дистинкцијата меѓу нив. Терминот ,јунак“ доаѓа од прасл. *јunъ: млад, *junakъ (пол. јunosza, јунак), лит. jaunas: млад $\leftarrow$ ie. *уewHno-: млад (лат. iuvenis, rep. Jung), а терминот „херој“ од грч. hếrōs co значење јунак. Според Петар Скок, „изразот јунак потекнува од латинскиот израз јuvenis во значење на млад јунак, т.е. херој (...). Оваа кованица потекнува од сесловенската и прасловенска придавка јунъ, шимо значи млая, од каде што Скок нѐ навраќа на индоевропскиот корен *ieu - кој исто така упатува на назначените моменти: млая, млаяо момче“ (курзиви К. Д. цит. спор. Лафазановска 2001: 305). „Современите етимолози му даваат различни толкувања на овој збор (херој - К. Д.) издвојувајќи ја од една страна функцијата на заштитата, на покровителството (индоевропскиот корен *ser-, варијантата *swer-, *wer-, лат. servare, „да се чува“, „да се спаси“), додека пак од друга страна, етимолошкото решение се јавува на релацијата херос - Хера“ (Тахо-Годи 1980: 294; цит. спор. Лафазановска 2001: 301). Веќе во етимологијата станува јасно дека јунакот е млаяо момче, а атрибутот на младоста упатува на недоволно животно искуство, на недоволно време да се искусат иницијации, кои би го претвориле или барем би го приближиле младото момче до стадиумот и статусот на (искусен) маж. Младоста упатува на несериозност, на неразумност, на недостаток од доволно животно искуство за да се донесе свесна процена за ризиците на одредени потфати. Терминот ,јунак“ упатува на некој кој е неискусен, некој кој поправо е неофит одошто е човек кој успешно минал низ иницијацијата. Иницијациските обреди се, всушност, еден од главните параметри за воспоставувањето на разликата меѓу ,јунакот“ и „херојот“. Херојот е младиот јунак, кој успешно минал низ иницијацијата. Добар пример за разликата меѓу двава термини може да се најде во англосаксонскиот еп Беовулф, во кој истоимениов лик ја почнува авантурата од позиција на јунак (битката со Грендел и триумфот над него) за да се закити со атрибутот херој (битката, односно йобеяайа ная Гренделовата мајка). ${ }^{6}$ По долгите години власт, стекнување на животно искуство и искуство во битки, Беовулф го предизвикува змејот кога е веќе $c \bar{u} а р$ крал.

Грендел во епот за Беовулф е границата што мора да ја мине јунакот (младиот, неискусен човек) за да стане општоприфатен херој (искусен човек, кој ја яокажал својата храброст). Јунаштвото е дадено, а херојството се стекнува. $^{7}$ Првото е факт, а второто потенцијал, можност. Не секој јунак има

\footnotetext{
${ }^{6}$ Кога оваа се одигрува, Беовулф просто само го докажува своето веќе стекнато херојство.

7 Ваквите суптилни нијанси во македонскиот јазик како да се резервирани само и стриктно за научни трудови или за научни расправи, особено за такви од областа на книжевноста и филозофијата на јазикот, бидејќи искуството со следење на новинарскиот дискурс или на говорот во политичките емисии - и уште повеќе на голем дел од новинарските натписи, - укажува на неспособноста на говорителите да направат разлика меѓу терминиве и понекогаш се добива впечаток или всушност се
} 
потенцијал да стане херој, затоа што херојството бара докажување, подразбира одреден степен на самопожртвуваност и извесен степен на проценета лудост, и донекаде претставува манифестација на највисоките човекови таленти, моќи и можности, па затоа претставува субверзија на еден општествен поредок. Херојството мора да се стекне и постојано и одново да се докажува, поради што претставува еден вид на егзалтација која се доживува како резултат на впрегнувањето на натчовечки сили и, следствено, резултира со постигнување на дело надвор од досегот на обичните луѓе. Не е доволно родителите да бидат со божествено потекло за ликот автоматски да биде крунисан за херој и еднаш-засекогаш да влезе во меморијата на другите како таков. ${ }^{8}$ Исто така, херојството е резервирано за посебните, за оние кои се издвојуваат од толпата поради ретки квалитети и поради тоа што е близу до невозможно да се имитира нивното однесување. Тие се, по автоматизам, исклучителни. Ако херојството беше едноставна работа, тогаш во македонската усна и пишана традиција, ќе постоеше само една епска песна за Марко Крале, а факт е дека тој во најголемиот број епски песни е јунак, но не и херој. Не сите епски песни во сржта содржат конфликт и нерамнотежа кои мораат да се разрешат, по што вообичаено следи триумфот на јунакот во форма на херојство. Марко Крале немаше да мора одново и повторно да се бори со толку многу различни непријатели, да минува низ толку многу различни, заплеткани сценарија и премрежиња, да приклонува кон итрина само за да си го спаси животот, ако херојството беше лесна и едноставна задача. ${ }^{9}$ Епските песни или, поправо, яобриие епски песни, се грандиозни токму поради тоа што го опеваат преодот на јунакот во херој и во ова е нивната суштина, во опевањето и во славењето на една несекојдневна трансформација. Зошто инаку епскиот пејач би се мачел постојано да пее за истото нешто, за Марко како јунак, кој не постигнува нешто значајно и величествено со својот живот? Најпросто речено, и меѓу многуте триумфи кои ги слави и опева, епската песна на суптилен начин го слави и преодот од младост во зрелост. Во претходнокажаново може да се согледа разлика меѓу Марко Крале и Турунџула Каравлашки како два слични, но по многу нешта

согледува фактот дека многумина не го промислуваат она што го кажуваат јавно и гласно, или дека, при пишувањето, не се обрнува внимание на пораката што се сака да се пренесе (како што се чудносрочените и нелогични наслови во првиот и во третиот пример во фуснота 4).

${ }^{8}$ Ахил, и покрај полубожественото потекло, и покрај докажаноста во претходни битки што му донеле репутација на успешен воин, мора да го брани и одново да го докажува своето херојство во Тројанската војна. Прашање на субјективна процена и суд е дали Ахиловиот kleos, кој очигледно предизвикува повеќе проблеми и главоболки одошто е причина за почести и пофалби, може да го окарактеризира неговото целокупно однесување како херојско.

9 Почесто се наведуваат примери за Марко Крале одошто за Турунџула Каравлашки од причина што епските песни за вториов обично се ориентирани кон женидбата на јунакот. 
различни ликови: првиот, во епските песни, почнува од позиција на наивен јунак, кој мора да победи, физички или со итрина, некој од него многу посилен противник, и со тоа да се стекне со статусот на херој, додека вториот речиси и воопшто и да не ја преминува границата од јунаштво кон херојство заради тоа што грабнувањето на невеста и не е баш некое херојско дело. А под „херојство“ или „херојско дело“ треба да се подразбере достигнување чиешто постигнување бара натчовечка сила, истрајност, храброст и пресметана лудост, со што ваквите достигнувања им се автоматски недостапни на „обичните“ луѓе. Од овие причини, херојството е спектакуларно и предизвикува восхит зашто е аномалија, а не норма, регуларност или рутина. ${ }^{10}$

Останува да му се посвети внимание и на терминот „антијунак“/,антихерој“. Во колоквијалниот говор, под овие називи вообичаено се подведува некој кој дејствува како противник на јунакот/херојот меѓутоа посоодветно би било тој да се именува како „ахерој“ зашто префиксот анти- имплицира негација на херојството (тој не е херој), а aхеројот не е само антитеза на јунакот/херојот, туку е микстура на позитивни и на негативни атрибути (не е само и единствено „лош“). Во епските песни, всушност, не може да се зборува за „ајунак“, туку само за „ахерој“, затоа што ограничениот обем на текстот не дозволува да се увидат можните иницијации низ кои потенцијално минал или би можел да мине овој лик и нему не му е посветено онолку внимание колку на јунакот или на херојот. Ваквиот недостаток не се должи на вината на епскиот пејач, кој не се осврнал доволно на градење на карактерот на ахеројот, туку просто станува збор за нужно ограничување наметнато од стихуваната форма на јазикот, која мора да зачува одредена структура и шема.

Проблемот со поистоветувањето на ,јунакот“ и на „херојот“ се должи и на репетитивната формула при епското пеење: „појунак од“ или ,јунак над (јунаци)“, која се толкува како „подобар од“ или, поправо, се должи на суперлативното „најдобар (од сите)“. Ако се има предвид дека дистинкцијата меѓу терминиве би требала да се прави на ниво на интерпретација (толкување на делото), а не на ниво на перформанс (пеење на епската песна), тогаш не ни може да се очекува дека епскиот пејач правел разлика меѓу двава термини кога пеел за одредено јуначко дело. Иако епскиот пејач не е наивен учесник во епскиот перформанс, тој сепак не е творец на текстот што го пее, што значи дека тој нема баш многу време да мудрува и филозофски да размислува за текстот, туку само го модифицира и додава свои „украси“, кои суштински не ја менуваат крајната порака. Дистинкцијата се прави или би требала да се прави, на интерпретативно рамниште, зашто во јазикот навистина е содржана меморијата за синонимијата меѓу „јунакот“ и „херојот“, меѓутоа јазикот е менлива материја, која секогаш може и треба да се преиспитува и соодветно да се прилагодува (односно да се дополнува и да се проширува) кога е

\footnotetext{
${ }^{10}$ Врз основа на големината на херојството, односно на херојското дело, може да се изврши и градација на видовите херои.
} 
потребно тоа. Со други зборови, македонскиот јазик, како и сите останати светски јазици, не е фиксиран и даден еднаш-засекогаш „од боговите“, што би имплицирало свет артефакт кој „не смее“ да се менува, туку преставува флуиден и еластичен систем кој се менува врз основа на заемен меѓучовечки договор.

\section{2. Апликативен дел: од јунак до херој}

Вреди низ примери да се согледа дистинкцијата меѓу термините јунак и херој, но и да се дадат примери и за останатите погореспоменати термини. Ако се искористи класификацијата што ја предлага Блаже Петровски, на поделба на епските песни за Марко Крале на четири групи (,Јуначко колено“, „Јуначки мегдани“, „Марко и самовили“ и „Други песни за Марко“; Петровски 1969), односно на песни со фантастично-историска и со јуначкоисториска предлошка (Петровски 1992), може да се предвиди дека во песните од групата „Јуначко колено“, односно во песните со фантастично-историска предлошка, ќе предоминира присуството на јунакот и на неговата фиксираност во ваквиот стадиум на постоење, додека во групата песни „Јуначки мегдани“ и песни со јуначко-историска предлошка, јасно ќе се увиди преминот (иницијацијата) на Марко од јунак во херој. Имајќи предвид дека станува збор за огромен корпус на епски песни чие истражување би резултирало да се развива трудов до недоглед, во полза на илустрација, ќе се наведат неколку егземпларни песни од секоја група, чие сиже е соодветно за претстава на разликата меѓу „јунаштвото“ и „херојството“ на Марко Крале, односно на Турунџула Каравлашки.

Божественото потекло на родителите не значи дека детето автоматски ќе биде херој. Добар пример што сведочи за ова е песната „Родня Марка Кралевича“ во која, откако триесетте јунаци му се пофалиле на Марко со своите мајки и братучеди, Марко се пофалил со својот коњ и сабја, на што добил критика за овие како минливи и небитни. Налутен, Марко се вратил дома, ја прашал мајка си за своето потекло, на што таа му одговорила дека неговиот татко бил кралот на земјата (па затоа и го нарекле Марко Кралевиќе), а неговата сестра била мажена за змеј. Е сега, и покрај ваквата „славна“ лоза, Марко сепак не е херој и останува на рамниште на обичен лик или на јунак поради очигледниот недостаток на иницијациско сценарио или на било каков подвиг, задача или мисија, која би требала да му овозможи трансфер од статусот на јунак во статусот на херој. Тој е протагонист, само затоа што дејството се врти околу него. За разлика од оваа песна, осмата песна „Седнал Марко со мајка вечера“, во која Марко ја продава мајка си за пари под изговорот дека му се потребни средства за женачка, го поттикнува прашањето дали ваквиот чин на продавање на мајката, убиството на Арапот што ја откупил и нејзиното спасување, можат да „поминат“ како херојски дела. Не. Ова е така затоа што херојското дејство вообичаено носи полза за поголема група луѓе, а не единствено за самиот херој во епското дејство. Па дури и ако херојскиот чин е побуден од славољубие, тој сепак завршува со дело од кое многумина, а не само херојот, имаат полза. Многу често херојството е 
несебичен и алтруистички чин, па така себството е игнорирано или се губи во полза на радоста на колективот. Во песнава, Марко е поправо и протагонист и антагонист, ${ }^{11}$ одошто јунак или херој, од причина што недостатокот на дуел или на конфликт со противник, го прави речиси невозможен трансферот од стадиумот на јунак во стадиумот на херој. Марко би можел да се дефинира како јунак само од аспект на непромислениот потег, кој би се поврзал за младоста како период во кој се донесуваат избрзани или неразумни одлуки.

Во песната „Марко си грабит невеста“ е застапен мотивот што доминира во речиси сите песни за Турунџула Каравлашки. Откако Марко успешно ја грабнува невестата и ја враќа кај мајка си, тој излегува или поправо се враќа назад на патот, за да се пресмета со „копилето“ што го гонело, за да увиди дека овој, всушност, не го гони за да се „бие“ со него, туку заради тоа што „бил јунак па ја грабнал [невестата; К. Д.; курзив мој]“ (Петровски 1969: 19). Се поставува прашањето: дали грабнувањето невеста е херојски чин? Јасно е дека Марко, во песнава, е јунак - тој е млад, стасан за женење, ${ }^{12}$ - но за да прерасне во херој, потребно е херојско дело. Проблемот со одговорот на ова прашање е што при толкувањето несвесно се наметнува современиот начин на размислување и понекогаш се применуваат вредносни критериуми што се актуелни за ова време (за времето на толкувањето), а што со сигурност биле инакви во времето кога се создавале и во времето кога писмено се фиксирале епските песни. На песната, исто така, треба да ѝ се пристапи како на уметнички, а не како на фактографски артефакт, така што одлуката да се карактеризира ваквото Марково дело како херојски чин, ке се должи на индивидуалните, а со тоа субјективни, вредносни судови и критериуми.

Исто така, друго битно прашање е потенцијалната алегоричност на епските песни. Дали „натпивањето“ треба да се чита како код, ${ }^{13}$ како

${ }^{11}$ Ваков е случајот во речиси сите песни поради амбивалентната природа на Марко Крале. Во некои песни тој „херојски“ грабнува невеста („Марко грабит Ангелина“ кај Цепенков), за во други песни („При првата си невеста Марко довежда друга“, „Марку ле, Крале, море Марку ле“, „Марко Јелена проштава“, „Елено, мори Елено“) да ја остави првата невеста и да земе друга, односно, да ја изневерува онаа што ја има („Ој, убава Гроздано невесто“), да ја „бие“ („Марко го бие своето љубне“) или во други грозоморни сценарија, да ѝ ја исече главата („Марко и канли Дука““ кај Верковиќ), рацете („Крали Марко, што му веле на нейна парва люба“) или жива да ја запали („Димни Марко и Елена невеста“).

12 Стапувањето на јунакот во брак не го менува автоматски неговиот статус во херојски.

${ }^{13}$ Ваквото прашање не е невообичаено затоа што некои епови, каков што е Oوисеја, можат да се читаат и преку една длабоко ритуалистичка визура. „Враќањето (nostos) на Одисеј во Oوисеја не значи само 'враќање“ или 'песна за враќањето', туку дури и 'враќање во светлината и животот'. Ова ритуалистичко значење... има врска со 'скриената агенда' на епот, за враќањето од Ад и за херојската тема на бесмртноста по смртта“ (Nagy 1990: 218-219; цит. спор. Nagy 2006: 18). Останува отворено прашањето дали епските песни за Марко Крале имаат потенцијал да бидат читани како нешто повеќе од она што го претставуваат на површината. 
способност којашто му е својствена исклучиво на херојот и како особина што го прави препознатлив? Во епските песни нема сигнали дека натпивањето ја зајакнува неговата сила, ниту пак дека на магичен начин ги удвојува неговите физички капацитети или пропорции; пиењето повеќе се задржува како фреквентна епизода во голем дел од епските песни затоа што се претворило во заштитен знак на епскиот херој, но и препознатлива сцена и релативно лесна епизода за инкорпорирање од страна на пејачот, како еден вид негова мнемотехничка операција, но нема некоја практична функција, како што е, на пример, спанаќот на Попај. Единствено во логиката на епскиот свет, натпивањето може да се толкува како херојски чин затоа што јунакот сепак прераснува во херој (поради тоа што успешно остварува одредена задача) и добар пример за ова се среќава во песната „Марко Кралевиќе и брат му Андријаш“, каде што благодарение на натпивањето, Марко си го спасува животот.

Песните „Ранил ми е ранил царо Сулимано“ и „Марко Крале, гости си кани“, го наметнуваат прашањето дали треба да се прави градација не само меѓу видовите херои, туку и меѓу видовите херојство. Во овие песни, Марко, не можејќи сам да го победи Муса, се потпира на советите на Фела самовила, односно на меанџиката Ѓруѓa, кои му помагаат со итрина да победи во двобојот против непријателот. Но, оваа победа не е вистинска херојска победа, туку е поправо резултат на Марковиот очајнички обид да си го спаси животот. Се поставува дилемата: дали јунакот прераснува во херој поради вложениот напор да ја измени, во своја полза, новонастанатата ситуација, која потенцијално му ветува повисок статус од оној што го уживал пред да налета на непријателот? Дали победата над противникот може да се смета за валидна ако јунакот добил помош отстрана, одгоре, од некој или од нешто што не е самиот тој што, следствено, значи дека не го постигнал триумфот сам? Дали херојството е анахоретски чин? Мора ли идниот херој да биде општествено изолиран и самотен, за да постигне победа? Во идеален свет, да, затоа што во пообемните епови, речиси сите победи над непобедливото се постигнале во самотија. Во многу наврати, Одисеј и Беовулф навистина не можат да се потпрат никому, освен на самите себе, па затоа и се присилени да излезат накрај со чудовиштето или со препреката што им излегла на патот. Би се рекло дека овие епски ликови се херои, во вистинска смисла на зборот, во споредба со Марко, кој приклонува кон итрина - ама не за да извојува победа, туку за да спаси жива глава, и благодарение на: силата, вештината, истрајноста или просто судбината или среќата (наклонетоста на Бог!), другите двајца докажуваат дека херојството подразбира крв, пот и солзи, дека јунакот и тоа како има да се намачи за да си го заслужи потенцијалниот повластен статус на херој меѓу своите побратими, и дека ќе треба одново и одново, од ден на ден, до крајот на животот, да го докажува своето херојство. Но, во случајов не треба да се изуми дека наведениве два епа, Oوисеја и Беовулф, претставуваат видови херои кои не се исклучиво епски, туку се донекаде и митски, што ги прави помалку реалистични во споредба со Марко, односно поблиски до бајката одошто до епската песна. Исто така, тешкотијата Марко Крале да се чита и да се толкува на исто рамниште како овие се должи како на 
неговата композитна природа, така и на неговото „расцепкано его“: тој не е униформен лик во еден целоснозаокружен еп, туку поправо е различна верзија на себеси во секоја различна песна која пее за него.

Во сто шеесет и четвртата песна најдобро може да се согледа преминот на Марко од јунак во херој. Јунакот е испровоциран, подбуцнат и ги презема нештата во свои раце; одговара на повикот за мегдан; на свиреп начин го убива антагонистот и со тоа ја воспоставува претходнонарушената рамнотежа. Не само што победата над непријателот може и треба да се толкува како херојски чин, бидејќи се елиминира заканата што го загрозува вообичаениот, нормален тек на нештата, туку херојот истовремено ги ослободува заробениците, што го прави неговото дело корисно и за останатите учесници во епската драма.

\section{ЗАКЛУЧОК}

Поради ограничениот обем на епската песна, која мора да се развива во строги, прецизни и однапред осмислени рамки, поради суштината на тоа во епскиот текст да не се посветува посебно внимание на дробно градење на карактерот на епскиот лик, на јунакот или на херојот, поради фрагментарноста или недовршеноста на многу епски песни, сосема е возможно да се јави тешкотија при детектирањето на преминот на јунакот во херој. Во некои песни, како што се четиринаесетте песни од првата група песни за Турунџула Каравлашки, воопшто и не доаѓ до премин на јунакот во херој и во овие песни, поради нивната тема и сиже, проблематизирањето на потенцијалното херојство и неговото отсуство е сосема ирелевантно.

Дистинкцијата меѓу јунакот и херојот што беше образложена во трудов немаше и нема да има цел да ги разубеди врвните познавачи на фолклористиката дека постои потреба да се прави разлика меѓу овие термини, ниту пак има тенденција да флертува со големите умови на фолклорната мисла, сакајќи да им го наметне овој предлог како нешто ново и спектакуларно во проучувањето на епските песни. Идејата беше да се покаже, теориски и апликативно, дека јазикот не треба секогаш да се прифаќа наивно, не треба секогаш да се користи здраво за готово и дека не претставува фиксиран и неменлив систем, туку поправо има потенцијал за подлабоки значења кога овие можат контекстуално да се оправдаат. Јазикот, како човечка творба, донекаде „се витка“ на човековата волја за разоткривање на суштински двојства во термините кои секојдневно ги користиме и таквото застранување од нормата е дозволено ако е аргументирано и продуктивно односно ако од него може да се изродат нови начини на користење, а со тоа и дезавтоматизирање, на еден даден термин. ${ }^{14}$ Јазичните конвенции се

\footnotetext{
${ }^{14}$ Иако јазикот го има потенцијалот да се менува и да се прилагодува на човековите потреби кои, како што се менуваат, така рефлектираат со потреби од промени и во јазикот, тој сепак, понекогаш, пожелно е да остане „фиксен“ и да се користи онака
} 
направени за да се почитуваат, но тие не се секогаш функционални. Ако го преиспитаме „она што ни е веќе добро познато“, тогаш можеме да откриеме потенцијал на јазикот да понуди и други значења, кои не се опфатени или се пренебрегнати во етимологијата или, поправо, во дефиницијата и дефинирањето на терминот што сакаме да го искористиме.

Со исцртувањето на суптилната, а сепак присутна и очигледна разлика меѓу јунакот и херојот во епските песни, трудов дава и основа за терминолошка дистинкција, која е применлива и во други книжевни и некнижевни родови и жанрови, затоа што ги изнесува пред вредносен суд дејствата и одлуките на ликовите, за да се увиди херојскиот потенцијал на нивниот начин на однесување (секако, онаму каде што текстот го дозволува тоа). Со други зборови, разликата меѓу двата загатнати термини не е ексклузивна само за епската песна или за епиката, што значи дека не е редуктивна, туку е применлива и во други родови, жанрови и видови. Понекогаш е потребна дистанцијација од веке усвоените термини и нивно претставување со нови потенцијални значења или потребно е барем да се направи ревизија на употребата на одредени термини кои се користат здраво за готово, чисто колку да се согледа дали терминот нуди нешто повеќе од она што го означува или можеби поседува квалитети кои не се очигледни на прв план.

\section{ЛИТЕРАТУРА}

\section{Кирилични изданија}

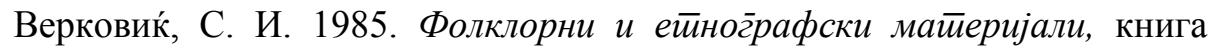
петта. Пенушлиски, К. (подг. и ред.). Скопје: Македонска книга.

Димовска, К. 2018. „(Епски) херои, опоненти, лудаци и антихерои“. Макеоонски фолклор, год. XL, бр. 76, 93-103.

Миладиновци, Д. и К. 1962. Зборник. Скопје: Кочо Рацин.

Петровски, Б. 1969. Прег̃леg на макеgонскийе нарояни иеесни за Крали Марко. Скопје: Институт за фолклор „Марко Цепенков““

како што гласи општиот консензус, ако овој е постоен. На пример, научните соработници и советници, професорите, академиците и воопшто авторите на научни трудови, трошат драгоцено време на техничко уредување на своите трудови по цена на научната вредност, издржаност, иновативност и корисност на трудот. Ова се должи на тоа што на државно рамниште сѐ уште не е усвоен, или, поправо, не е прифатен еден и единствен, и пред сѐ едноставен, начин на наведување на користените извори во еден труд, и покрај тоа што таков е веќе даден во Правописот на македонскиот јазик (2017, второ издание). Техничкото уредување на трудот треба да е најмалиот проблем на авторот, сѐ додека прописно, детално и точно се наведат сите цитирани материјали. 


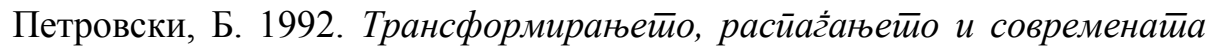
сост̄ојба на макеоонскиоти јуначки ейос. Скопје: Институт за фолклор „Марко Цепенков“.

Стојановиќ-Лафазановска, Л. 2001. Ното initiatus. Феномено $\bar{u}$ на

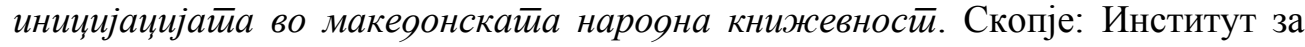
фолклор „Марко Цепенков““.

Цепенков, М. 1980. Народни песни, прва книга. Пенушлиски, К. (ред.). Скопје: Институт за фолклор.

\section{Латинични изданија}

Nagy, G. 2006. “The Epic Hero", $2^{\text {nd }}$ ed. (online version), Center for Hellenic Studies, Washington, DC https://chs.harvard.edu/curated-article/gregory-nagy-theepic-hero/ [Пристапено на 31.8.2021 г.].

\section{Сајтографија}

„Јунак, значење и дефиниција“ $\mathrm{https://jezikoslovac.com/word/d84z}$ [Пристапено на 1.9.2021 г.]

„ХЕРОЈСКИ. Македонија славеше против Шкотска“ https://ffm.mk/herojski-makedonija-slaveshe-protiv-shkotska [Пристапено на 1.9.2021 г.]

„Твит“ на претседателот на РС Македонија Стево Пендаровски https://mobile.twitter.com/spendarovski/status/1407042737396981764

[Пристапено на 8.11.2021 г.].

„Херојски: Се врати по тешката скршеница на черепот и веќе постигнува голови“ skrshenica-na-cherepot-i-vekje-postignuva-golovi-video/ [Пристапено на 1.9.2021 г.]

„17-годишниот херој-спасувач од Истанбул“ https:/www.dw.com/mk/17-

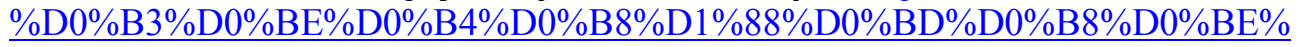
D1\%82-\%D1\%85\%D0\%B5\%D1\%80\%D0\%BE\%D1\%98$\% \mathrm{D} 1 \% 81 \% \mathrm{D} 0 \% \mathrm{BF} \% \mathrm{D} 0 \% \mathrm{~B} 0 \% \mathrm{D} 1 \% 81 \% \mathrm{D} 1 \% 83 \% \mathrm{D} 0 \% \mathrm{~B} 2 \% \mathrm{D} 0 \% \mathrm{~B} 0 \% \mathrm{D} 1 \% 87-$ $\% \mathrm{D} 0 \% \mathrm{BE} \% \mathrm{D} 0 \% \mathrm{~B} 4-$ $\%$ D0\%B8\%D1\%81\%D1\%82\%D0\%B0\%D0\%BD\%D0\%B1\%D1\%83\%D0\%BB/a49429704 [Пристапено на 8.11.2021 г.]

Kristina Dimovska

\section{THE IMPORTANCE OF THE DISTINCTION BETWEEN JUNAK AND HERO AND ITS RELEVANCE IN EPIC SONG INTERPRETATION}

\section{Summary}

The paper tried to present and to elaborate the possible distinction between what is called epic "junak" in Southslavic and Macedonian epic songs and its apparent synonym the epic "hero". Even though both of the terms are often used as synonymous in the 
Macedonian language (which is not an issue in the English language since there isn't an English term, aside from "protagonist", similar in meaning to the Macedonian "junak"), we tried to pinpoint that a possible difference is, in fact, plausible and that the junak is not the same as the hero. There can be many junaci but only one hero. The junak is often a young person, often a male, who in epic songs is represented as inexperienced in life and battle. In comparison, the hero is someone who is already established as heroic because of a triumphant deed he has acomplished (slaying a formidable enemy, saving slaves from their misfortune, etc.) and more often than not, possesses qualities and attributes that are superhuman or rather not easily obtainable by regular mortals.

The distinction between the two terms is semantic but also raises questions which can be thoroughly examined in the spheres of philosophy of language. Heroism is something that needs to be earned and continuously proven, unlike junaštvo which does not testify the uniqueness of the epic agent, its rare qualities and talents nor is a testament of his rare capabilities of triumphs and victories. Therefore, the epic hero should be considered as an anomaly, a deviation, which is the opposite of compliance to the (social, cultural, etc.) norm. 